\title{
Proteome changes in ileal mucosa of young pigs resulting from different levels of native chicory inulin in the diet
}

\author{
A. Herosimczyk ${ }^{1,3}$, A. Lepczyński', M. Ożgo'1, M. Barszczz, M. Marynowska', A. Tuśnio², \\ M. Taciak², A. Markulen ${ }^{1}$ and J. Skomiał ${ }^{2}$ \\ ${ }^{1}$ West Pomeranian University of Technology, Department of Physiology, Cytobiology and Proteomics \\ Klemensa Janickiego 29, 71-270 Szczecin, Poland \\ ${ }^{2}$ The Kielanowski Institute of Animal Physiology and Nutrition, Polish Academy of Sciences, Department of Animal Nutrition \\ Instytucka 3, 05-110 Jabłonna, Poland
}

KEY WORDS: pigs, ileum, proteomes, chicory, inulin

Received: 27 September 2017

Revised: $\quad 7$ June 2018

Accepted: 6 August 2018

${ }^{3}$ Corresponding author:

e-mail: agnieszka.herosimczyk@zut.edu.pl

\begin{abstract}
The analysis of mucosa proteomes was performed using a twodimensional electrophoresis combined with mass spectrometry to determine the effect of dietary level of inulin on protein expression patterns in the ileum. The experiment was carried out on 24 castrated male piglets, allocated to three groups, fed from the day 10 of life an unsupplemented diet $(\mathrm{C})$ or diet supplemented with $1 \%$ (T1) or $3 \%$ (T2) of native chicory inulin. Samples of ileal tissue and blood were collected after 40 days of feeding. Comparative proteomic analysis of the T1 group showed 10 protein spots with a decreased expression, whereas the T2 diet caused overexpression of 24 spots in comparison to the $C$ diet. Inulin levels differed in their effects on the expression of ileal proteins involved in intracellular molecular mechanisms controlling cell division and growth. The T1 diet down-regulated, whereas the T2 diet induced substantial up-regulation of proteins engaged in transcriptional and translational activities, folding and posttranslational modifications, which may indicate stimulation of epithelial cell proliferation. Inulin did not affect plasma levels of phosphorus, magnesium, calcium and iron in piglets but improved plasma prooxidant-antioxidant balance in animals fed the T2 diet. The results of this study might be considered as preliminary since further confirmation using more sophisticated quantitative proteomic tools is required to better understand and answer the unresolved issues concerning the mechanism underlying the inulin effect on the ileum in growing pigs. Nevertheless, a general insight into how inulin molecules or their fermentation end-products may induce changes in protein expression patterns in the ileum was presented.
\end{abstract}

\section{Introduction}

In recent years, a wide variety of prebiotics, including inulin, has gained researchers attention as possible feed additives due to their possible positive effects on intestinal health, and thus young animal performance. The root of Cichorium intybus $\mathrm{L}$. is considered one of the most important sources of inulin, consisting of $15-20 \%$ of this prebiotic (Niness, 1999). Chicory inulin is a mixture of linear oligomers and polymers composed of $\beta$-D-fructosyl units linked together by $(2 \rightarrow 1)$ glycosidic bonds.

Its degree of polimerisation (DP) ranges from 2 to 60 fructose monomers with an average $10-12$ DP 
(Mensink et al., 2015). Previous studies on microbial profiles and activities in the gastrointestinal tract of pigs demonstrated that the effects of inulin were depended on dietary level, DP and intestinal segment (Yasuda et al., 2007; Patterson et al., 2010; Barszcz et al., 2018). The results of these studies also indicated that inulin $(1-4 \%$ addition to diets of growing pigs, average $\mathrm{DP} \geq 23$ ) was predominantly fermented in the large intestine, mainly in the caecum (Yasuda et al., 2007; Patterson et al., 2010; Barszcz et al., 2018). On the other hand, in the previous study by Loh et al. (2006) was shown that a significant amount of chicory inulin with an average DP of $12(20-50 \%)$ was fermented in the porcine jejunum by the resident microflora. Similar observations were reported by Böhmer et al. (2005), who found $57 \%$ precaecal digestibility of inulin in pigs fed diet supplemented with $2 \%$ of this carbohydrate. Considering the above results, it was hypothesized that inulin implementation with an average DP of 10 into the diet of growing pigs would induce proteome changes in the ileum resulting from its earlier degradation. The results of this study might help to gain additional insight into how inulin may transmit signals changing protein expression patterns in the ileum, and thereby provide an additional evidence demonstrating its prebiotic effect on the distal part of the pig small intestine. Therefore, the influence of feeding young pigs a diet supplemented with $1 \%$ and $3 \%$ of native chicory inulin with an average DP of 10 on the expression of ileal mucosa proteins was evaluated.

\section{Material and methods}

\section{Animals and sample collection}

In total 24 castrated male piglets $(\mathrm{PIC} \times$ Penarlan P76) were used in the study. Animals were allocated to three experimental groups $(n=8)$. At the beginning of the experiment piglets were kept with their sows (4 sows and litters per group) in farrowing pens, on a commercial farm. Sows and their litters were randomly allotted to the different treatments. The sows were in the third or fourth parity. During the first 9 days of life piglets received only colostrum and milk of their mothers, while from the day 10 of life they were offered a milkbased diet with the addition of a solid-feed diet. The control group (C group) received an unsupplemented cereal-based diet and the experimental groups - a diet supplemented with $1 \%$ (treatment group $1, \mathrm{~T} 1$ ) or $3 \%$ of native chicory inulin (treatment group 2, T2). Inulin (Inulin Orafti ${ }^{\circledR} \mathrm{GR}$, BENEO $\mathrm{GmbH}$, Mannheim, Germany) containing approximately $92 \%$ of inulin with DP $\geq 10$ and $8 \%$ of other carbohydrates (glucose, fructose and sucrose) was included into the diets instead of maize starch. The remaining components of the diet were, \%: wheat 46.84, barley 20, maize starch 3 in C, 2 in T1 and 0 in T2, full-fat soybean 5.90, whey 9.70 , fish meal 4, spray-dried blood plasma 4 , soybean oil 3.40 , calcium formate 0.30 , limestone 0.50 , dicalcium phosphate 0.60 , sodium chloride 0.07 , L-lysine 0.61 , DL-methionine 0.23 , L-threonine 0.26 , L-tryptophan 0.09 , mineral-vitamin premix 0.40 and aroma 0.10 . All diets contained, \%: crude protein 20, crude ash 4.54, crude fibre 1.52 and $14.3 \mathrm{MJ} / \mathrm{kg}$ of metabolizable energy. The composition of the diets was previously described by Barszcz et al. (2018). At day 28 of life piglets were weaned and then 2 males from each litter were chosen and transported to the experimental facility. The solid based diets were offered ad libitum and its composition has not been changed through the whole experiment. Animals had free access to water. Feed intake and health status was monitored every day during the experimental period. At the age of 50 days animals were stunned by electric shock and killed by exsanguination. The samples of mixed blood were collected into heparinized tubes and plasma for biochemical analyses was obtained by centrifugation at $3000 \mathrm{~g}$ for $10 \mathrm{~min}$ at $4{ }^{\circ} \mathrm{C}$ and stored at $-40{ }^{\circ} \mathrm{C}$ until further analyses. Ileal tissue samples were taken immediately and washed twice with $0.9 \% \mathrm{NaCl}$ and thereafter twice with $20 \mathrm{mM}$ Krebs-HEPES buffer $(99 \mathrm{mM} \mathrm{NaCl}, 4.69 \mathrm{mM} \mathrm{KCl}$, $2.50 \mathrm{mM} \mathrm{CaCl}_{2}, 1.20 \mathrm{mM} \mathrm{MgSO}_{4}, 1.03 \mathrm{mM} \mathrm{K}_{2} \mathrm{HPO}_{4}$, $25 \mathrm{mM} \mathrm{NaHCO}, 5.60 \mathrm{mM} \mathrm{D}-(+)$-glucose, $\mathrm{pH} 7.4)$. Tissue samples were snap frozen in liquid nitrogen and then stored at $-80{ }^{\circ} \mathrm{C}$ until further analysis. The experimental procedures were approved by the Local Commission of Ethics for the Care and Use of Laboratory Animals (No. 13/2012, Poland).

\section{Protein extract preparation}

Ileal mucosa was removed by scrubbing with a glass slide on plastic plate and then homogenized in $1000 \mu 1$ of lysis buffer (7 M urea, $2 \mathrm{M}$ thiourea, $4 \% \mathrm{w} / \mathrm{v}$ CHAPS, $1 \% \mathrm{w} / \mathrm{v}$ DTT, $2 \% \mathrm{v} / \mathrm{v}$ Biolyte, $1 \% \mathrm{v} / \mathrm{v}$ protease inhibitor cocktail, $0.1 \% \mathrm{v} / \mathrm{v}$ nuclease) at a frequency of $20000 \mathrm{~Hz}$ for $60 \mathrm{~min}$ using a mechanical homogenizer (Tissue Lyser, Qiagen, Hilden, Germany). Insoluble tissue debris were removed by centrifugation $\left(4^{\circ} \mathrm{C}, 15000 \mathrm{~g}, 15 \mathrm{~min}\right)$ and the supernatant was used for two-dimensional electrophoresis. 


\section{Two-dimensional electrophoresis (2-DE)}

Analyses were performed in duplicate. A modified Bradford assay (Bio-Rad Protein Assay, BioRad, Hercules, CA, USA) was used to estimate total protein concentration. Samples containing $1000 \mu \mathrm{g}$ of proteins were mixed with lysis buffer to the total volume of $650 \mu 1$ and applied to 3-10, $24 \mathrm{~cm}$ ReadyStrip ${ }^{\mathrm{TM}}$ IPG Strips (Bio-Rad, Hercules, CA, USA). Isoelectrofocusing was run using Protean ${ }^{\circledR}$ IEF Cell (Bio-Rad, Hercules, CA, USA) by ramping the voltage to a maximum of $5000 \mathrm{~V}$ and terminated when a total of $90000 \mathrm{Vh}$ was reached. The strips were reduced with DTT in equilibration buffer $(6 \mathrm{M}$ urea, $0.5 \mathrm{M}$ Tris $/ \mathrm{HCl}, \mathrm{pH} 6.8,2 \% \mathrm{w} / \mathrm{v}$ SDS, $30 \% \mathrm{w} / \mathrm{v}$ glycerol and $1 \% \mathrm{w} / \mathrm{v}$ DTT) for $15 \mathrm{~min}$ and then alkylated with iodoacetamide $(2.5 \% \mathrm{w} / \mathrm{v})$ for $20 \mathrm{~min}$. The second dimension was run on $12 \%$ SDS polyacrylamide gels $(20 \times 25 \mathrm{~cm})$ at $100 \mathrm{~V}$ for $17 \mathrm{~h}$ at $15{ }^{\circ} \mathrm{C}$ using a Protean Plus ${ }^{\mathrm{TM}}$ Dodeca Cell ${ }^{\mathrm{TM}}$ electrophoretic chamber (Bio-Rad, Hercules, CA, USA). After electrophoretic separation, the gels were stained with colloidal Coomassie Brilliant Blue G-250 (SigmaAldrich, St. Louis, MO, USA).

\section{Image acquisition and data analysis}

Gel image acquisition was performed using a GS-800 ${ }^{\mathrm{TM}}$ Calibrated Densitometer (Bio-Rad, Hercules, CA, USA). 2-D images were analysed using PDQuest Analysis software version 8.0.1 Advanced (Bio-Rad, Hercules, CA, USA). The spots present on at least four gels from each group were designated as expressed protein spots and were further analysed. The gel that displayed the highest number of spots was marked as the master gel for matching the remaining gels. The spot volume was used as the parameter for quantifying protein expression after normalisation based on the local regression model. After normalisation, the volume of each spot was averaged for two replicates of each biological sample. To measure the variability within the group, the coefficients of variation (CV) were calculated and additionally for each protein spot the mean spot quantity value was calculated. The level of statistical significance $(P<0.01$ or $P<0.05)$ was first used to select differential protein spots that then were ranked by a fold-change with a cut-off of 1.5. The degree of difference between protein groups was expressed as an average ratio. The ratio values are presented in Table 1 for the T1 group (C vs T1) and in Table 2 for the T2 group (C vs T2). Based on the standard 2-D markers, the experimental isoelectric point $(\mathrm{pI})$ and molecular weight $\left(\mathrm{M}_{\mathrm{r}}\right)$ values were computed for each identified protein spot.

\section{Mass spectrometry and bioinformatic data analysis}

Protein spots were excised from the gels and washed in a solution of $25 \mathrm{mM} \mathrm{NH}_{4} \mathrm{HCO}_{3}$ in $5 \% \mathrm{v} / \mathrm{v}$ acetonitrile (ACN), followed by two washes with a buffer containing $25 \mathrm{mM} \mathrm{NH}_{4} \mathrm{HCO}_{3}$ in $50 \% \mathrm{v} / \mathrm{v}$ ACN. The gel pieces were dehydrated with $100 \%$ ACN, dried by centrifugation under vacuum and further digested overnight with trypsin $(20 \mu 1 /$ spot of $12.5 \mu \mathrm{g}$ trypsin/ml in $25 \mathrm{mM} \mathrm{NH}{ }_{4} \mathrm{HCO}_{3}$; Promega, Madison, WI, USA) at $37^{\circ} \mathrm{C}$. After digestion, the peptides were extracted with $100 \% \mathrm{ACN}$, combined with the matrix solution $(5 \mathrm{mg} / \mathrm{ml} \mathrm{CHCA}, 0.1 \% \mathrm{v} / \mathrm{v}$ TFA, $50 \% \mathrm{v} / \mathrm{v}$ ACN) and placed onto a MALDIMSP AnchorChip ${ }^{\text {TM }}$ 600/96 plate (Bruker Daltonics, Hamburg, Germany) in a final volume of $1 \mu \mathrm{l}$. Droplets were allowed to dry at room temperature. A Microflex ${ }^{\mathrm{TM}}$ MALDI-TOF (matrix-assisted laser desorption/ionization time of flight) mass spectrometer (Bruker Daltonics, Hamburg, Germany) was operated in positive ion reflector mode. External calibration was performed using a Peptide Mass Standard II (Bruker Daltonics, Hamburg, Germany) based on monoisotopic values of the following peptides: bradykinin 1-7 (757.3992 Da), angiotensin II (1046.5418 Da), angiotensin I (1296.6848 Da), substance P (1347.7354 Da), bombesin (1619.8223 Da), ACTH clip 1-17 (2093.0862 Da), ACTH clip 18-39 (2465.1983 Da) and somatostatin $28(3147.4710 \mathrm{Da})$. The mass spectra were acquired with 150 shots of a nitrogen laser operating at $20 \mathrm{~Hz}$ and were internally calibrated using porcine tryptic autolytic products (842.51 and $2211.10 \mathrm{~m} / \mathrm{z})$. Peptide mass fingerprinting (PMF) data were compared to mammalian databases (SWISS-PROT; http://us.expasy.org/uniprot/ and NCBI; http://www.ncbi.nlm.nih.gov/) with the aid of MASCOT search engine (http://www.matrixscience.com/). Search criteria included: trypsin as an enzyme, carbamidomethylation of cysteine as a fixed modification, methionine oxidation as a variable modification, mass tolerance to $150 \mathrm{ppm}$ and a maximum of one missed cleavage site. Contaminating peaks of keratin and trypsin were removed from the peptide mass list prior to database search. The results of PMF-based identification were accepted when the protein score was significant $(P<0.05)$ with at least five matching peptides and $25 \%$ peptide coverage.

\section{Analysis of biochemical parameters of blood plasma}

Biochemical blood parameters were determined spectrophotometrically using ready-to-use reagents 


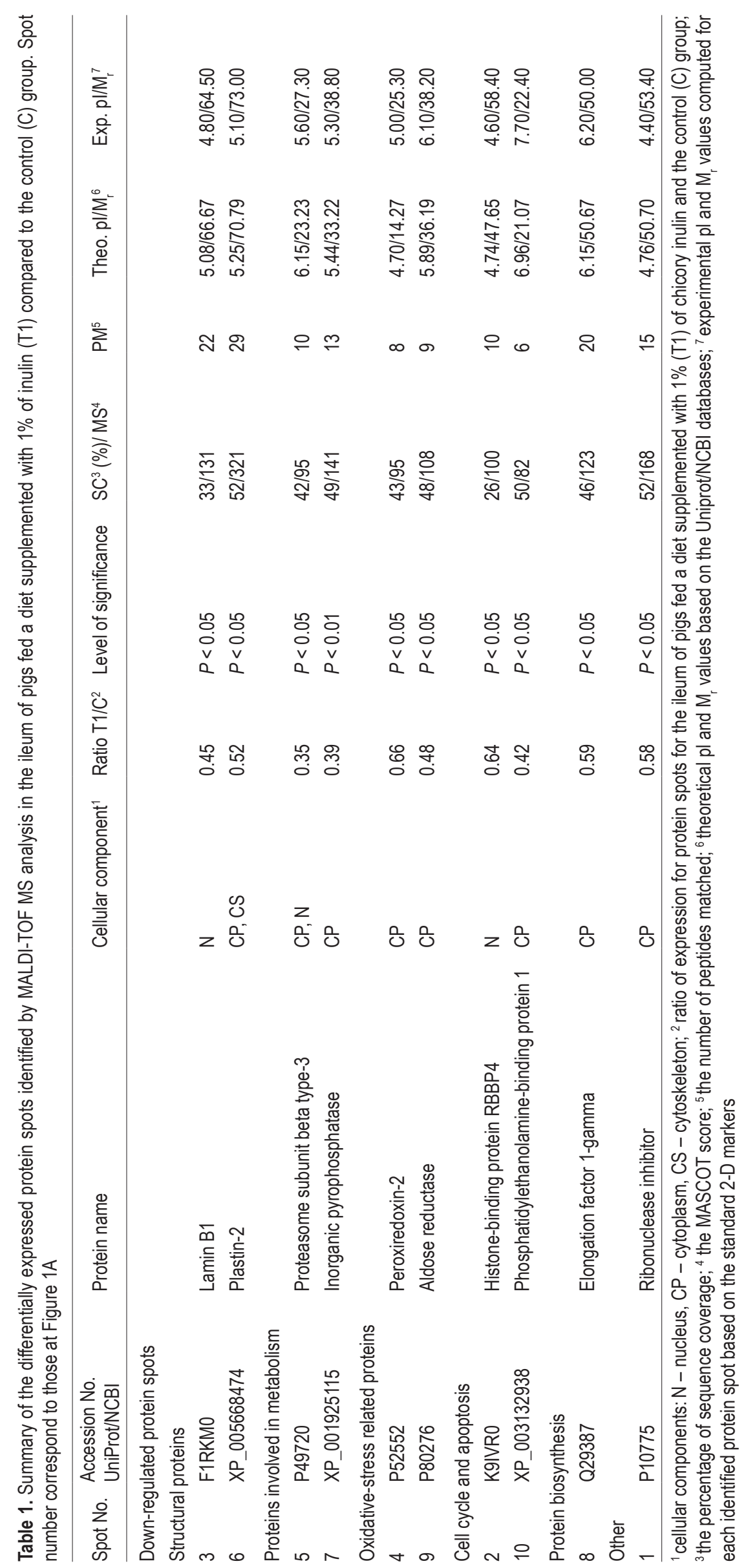


Table 2. Summary of the differentially expressed protein spots identified by MALDI-TOF MS analysis in the ileum of pigs fed a diet supplemented with $3 \%$ of inulin (T2) compared to the control (C) group. Spot number correspond to those at Figure 1B.

\begin{tabular}{|c|c|c|c|c|c|c|c|c|c|}
\hline $\begin{array}{l}\text { Spot } \\
\text { no. }\end{array}$ & $\begin{array}{l}\text { Accession no. } \\
\text { UniProt/NCBI }\end{array}$ & Protein name & $\begin{array}{l}\text { Cellular } \\
\text { component }^{1}\end{array}$ & $\begin{array}{l}\text { Ratio } \\
\mathrm{T} 2 / \mathrm{C}^{2}\end{array}$ & $\begin{array}{l}\text { Level of } \\
\text { significance }\end{array}$ & $\begin{array}{l}\mathrm{SC}^{3}(\%) / \\
\mathrm{MS}^{4}\end{array}$ & $\mathrm{PM}^{5}$ & $\begin{array}{l}\text { Theo. } \\
\mathrm{pl} / \mathrm{M}_{\mathrm{r}}^{6}\end{array}$ & $\begin{array}{l}\text { Exp. } \\
\mathrm{pl} / \mathrm{M}_{\mathrm{r}}^{7}\end{array}$ \\
\hline \multicolumn{10}{|c|}{ Up-regulated protein spots } \\
\hline \multicolumn{10}{|c|}{ Structural proteins } \\
\hline 6 & Q2XVP4 & Tubulin alpha-1B chain & $\mathrm{CP}, \mathrm{CS}$ & 1.83 & $P<0.05$ & $32 / 78$ & 9 & $4.94 / 50.80$ & $6.00 / 58.50$ \\
\hline 12 & XP_005659576 & Tropomyosin alpha- 1 chain isoform $\mathrm{X} 3$ & $\mathrm{CP}, \mathrm{CS}$ & 3.31 & $P<0.01$ & $41 / 170$ & 17 & $4.67 / 32.62$ & $4.30 / 42.60$ \\
\hline 14 & XP_005659583 & Tropomyosin alpha- 1 chain isoform $X 9$ & $\mathrm{CP}, \mathrm{CS}$ & 2.98 & $P<0.05$ & $38 / 115$ & 17 & $4.71 / 32.54$ & $4.40 / 38.90$ \\
\hline 13 & NP_001123419 & Tropomyosin beta chain & $\mathrm{CP}, \mathrm{CS}$ & 3.18 & $P<0.01$ & $55 / 186$ & 23 & $4.62 / 33.38$ & $4.30 / 42.60$ \\
\hline 24 & P29269 & Myosin regulatory light polypeptide 9 & $\mathrm{CP}$ & 4.47 & $P<0.01$ & $40 / 74$ & 8 & $4.80 / 19.87$ & $4.70 / 20.00$ \\
\hline 23 & P19105 & Myosin regulatory light chain $12 \mathrm{~A}$ & $\mathrm{CP}$ & 2.25 & $P<0.05$ & $40 / 72$ & 6 & $4.67 / 19.84$ & $4.40 / 19.90$ \\
\hline 9 & XP_005668164 & Vimentin isoform X2 & $\mathrm{CP}, \mathrm{CS}$ & 2.17 & $P<0.05$ & $33 / 98$ & 13 & $5.09 / 49.25$ & $4.40 / 57.90$ \\
\hline 18 & EDL81026 & $\begin{array}{l}\text { EF hand domain containing 2, } \\
\text { isoform CRA_a }\end{array}$ & $\mathrm{CT}$ & 2.40 & $P<0.01$ & $35 / 79$ & 6 & $6.23 / 20.46$ & $4.90 / 33.70$ \\
\hline \multicolumn{10}{|c|}{ Proteins involved in metabolism } \\
\hline 1 & NP_999445 & $\begin{array}{l}\text { Transitional endoplasmic reticulum } \\
\text { ATPase }\end{array}$ & CP, ER, N & 3.15 & $P<0.05$ & $28 / 148$ & 22 & $5.13 / 89.92$ & $5.00 / 104.40$ \\
\hline 2 & NP_999445 & $\begin{array}{l}\text { Transitional endoplasmic reticulum } \\
\text { ATPase }\end{array}$ & CP, ER, N & 1.72 & $P<0.05$ & $33 / 150$ & 18 & $5.13 / 89.92$ & $5.10 / 105.80$ \\
\hline 19 & NP_001138373 & Proteasome subunit alpha type- 5 & $\mathrm{CP}, \mathrm{N}$ & 2.10 & $P<0.01$ & $56 / 97$ & 10 & $4.74 / 26.41$ & $4.40 / 29.10$ \\
\hline 20 & XP_005662207 & Phosphomannomutase 2 & CS & 1.75 & $P<0.01$ & $32 / 95$ & 9 & $5.19 / 28.39$ & $4.90 / 29.90$ \\
\hline \multicolumn{10}{|c|}{ Cell cycle and apoptosis } \\
\hline 3 & XP_003360037 & $\begin{array}{l}\text { Protein-glutamine gamma- } \\
\text { glutamyltransferase } 2\end{array}$ & $\mathrm{CT}, \mathrm{ER}$ & 3.36 & $P<0.01$ & $32 / 163$ & 15 & $5.19 / 78.20$ & $5.10 / 95.00$ \\
\hline 10 & XP_003360037 & $\begin{array}{l}\text { Protein-glutamine gamma- } \\
\text { glutamyltransferase } 2\end{array}$ & $\mathrm{CT}, \mathrm{ER}$ & 1.80 & $P<0.05$ & $56 / 271$ & 34 & $5.19 / 78.20$ & $4.80 / 55.60$ \\
\hline 5 & P54612 & $\begin{array}{l}\text { Serine/threonine-protein phosphatase } \\
2 \mathrm{~A} 65 \mathrm{kDa} \text { regulatory subunit } \mathrm{A} \text { alpha } \\
\text { isoform }\end{array}$ & $\mathrm{CP}, \mathrm{N}$ & 2.17 & $P<0.05$ & $41 / 137$ & 18 & $5.00 / 66.10$ & $5.10 / 71.50$ \\
\hline \multicolumn{10}{|c|}{ Protein biosynthesis } \\
\hline 15 & XP_005653148 & Elongation factor 1-delta isoform X1 & $\mathrm{N}, \mathrm{CP}$ & 1.83 & $P<0.01$ & $42 / 99$ & 11 & $4.94 / 31.13$ & $4.80 / 37.80$ \\
\hline 16 & XP_005653148 & Elongation factor 1-delta isoform X1 & $\mathrm{N}, \mathrm{CP}$ & 1.56 & $P<0.05$ & $46 / 130$ & 14 & $4.94 / 31.13$ & $4.90 / 37.80$ \\
\hline 11 & NP_001032223 & $40 \mathrm{~S}$ ribosomal protein SA & $\mathrm{CM}, \mathrm{CP}, \mathrm{N}$ & 1.63 & $P<0.01$ & $52 / 139$ & 12 & $4.80 / 33.02$ & $4.60 / 46.60$ \\
\hline \multicolumn{10}{|c|}{ Chaperone proteins } \\
\hline 4 & P28491 & Calreticulin & CP, ER & 2.40 & $P<0.01$ & $50 / 183$ & 16 & $4.32 / 48.43$ & $3.80 / 54.00$ \\
\hline 7 & G9F6X8 & Protein disulfide isomerase & ER & 1.67 & $P<0.05$ & $40 / 144$ & 15 & $4.78 / 56.76$ & $4.60 / 61.90$ \\
\hline \multicolumn{10}{|c|}{ Calcium-binding proteins } \\
\hline 17 & XP_003129266 & Annexin A5 & CS & 2.74 & $P<0.01$ & $41 / 123$ & 11 & $4.94 / 36.17$ & $4.90 / 34.30$ \\
\hline 22 & F1S340 & Sorcin & $\mathrm{CP}$ & 2.14 & $P<0.01$ & $43 / 82$ & 9 & $5.32 / 21.73$ & $5.10 / 20.40$ \\
\hline \multicolumn{10}{|l|}{ Other } \\
\hline 8 & P10775 & Ribunuclease inhibitor & $\mathrm{CP}$ & 2.13 & $P<0.05$ & $29 / 85$ & 9 & $4.76 / 50.70$ & $4.40 / 53.40$ \\
\hline 21 & & Not identified & & 2.02 & $P<0.01$ & & & & $5.10 / 27.00$ \\
\hline
\end{tabular}

${ }^{1}$ cellular components: CP - cytoplasm, CS - cytoskeleton, CT - cytosol, ER - endoplasmic reticulum, $\mathrm{N}$ - nucleus, CM - cell membrane;

${ }^{2}$ ratio of expression for protein spots for the ileum of pigs fed a diet supplemented with $3 \%$ (T2) of chicory inulin and the control (C) group; ${ }^{3}$ the percentage of sequence coverage; ${ }^{4}$ the MASCOT score; ${ }^{5}$ the number of peptides matched; ${ }^{6}$ theoretical pl and $\mathrm{M}_{\mathrm{r}}$ values based on the Uniprot/ $\mathrm{NCBI}$ databases; ${ }^{7}$ experimental $\mathrm{pl}$ and $\mathrm{M}_{\mathrm{r}}$ values computed for each identified protein spot based on the standard 2-D markers

(ELITech Group, Puteaux, France). The prooxidantantioxidant balance $(\mathrm{PAB})$ in blood plasma was determined according to the method of Koliakos and Hamidi Alamdari (2009). All analyses were performed on a MAXMAT PL multidisciplinary diagnostic platform (Erba Diagnostics France SARL, Montpellier, France).

\section{Statistical analysis}

The mean values and standard error of the mean (SEM) were calculated. Biochemical blood parameters were analysed by one-way analysis of variancefollowed by Tukey's test using STATGRAPHICS ${ }^{\circledR}$ Centurion XVI ver. 16.1.03 statistical package (StatPoint Technologies, Inc., Warrenton, VA, USA). 

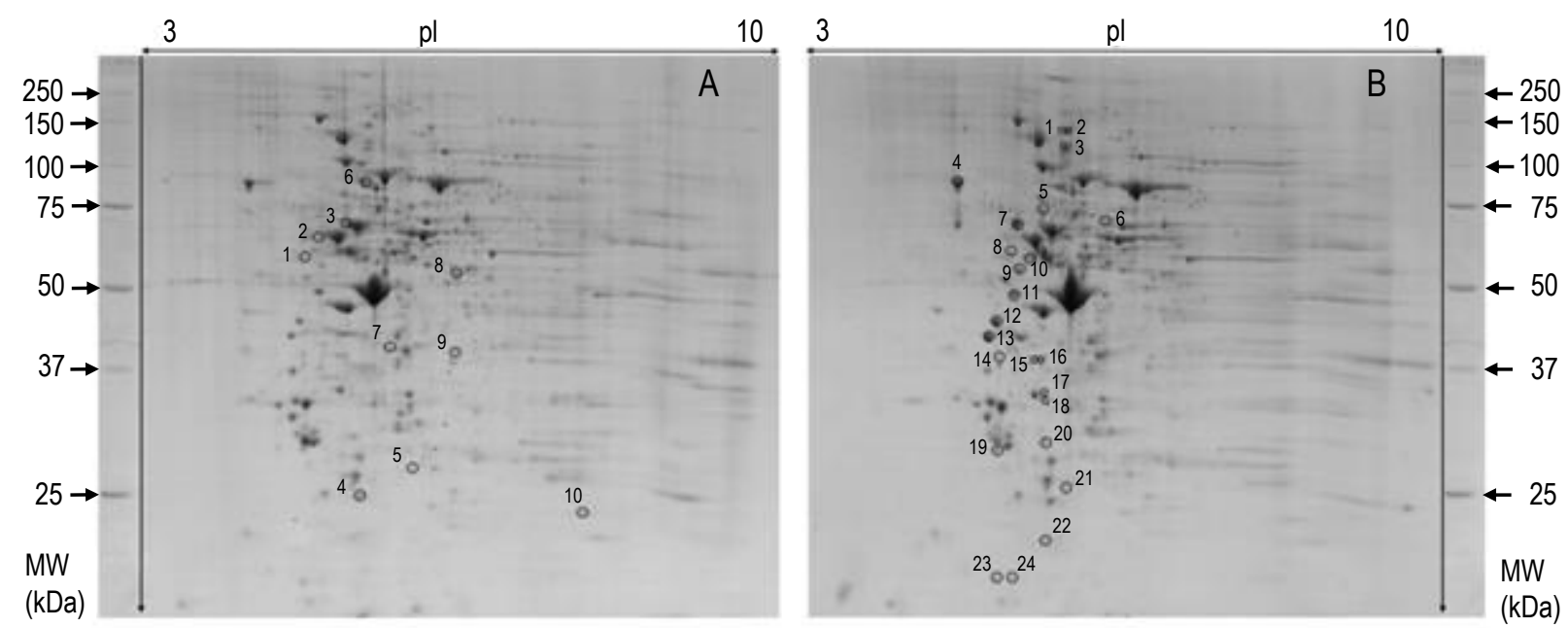

Figure 1. Representative two-dimensional (2-D) gel images presenting differentially expressed ileal protein spots found in growing piglets fed diets supplemented with $1 \%$ (A) or $3 \%$ (B) of native chicory inulin. $1000 \mu \mathrm{g}$ of proteins were applied on the IPG strips (24 cm, pH 3-10) for the first dimension, the second dimension was performed on a 12\% SDS-PAGE gels that were stained with Coomassie Brilliant Blue G-250. Spot numbers correspond to those in Tables 1 and 2

The significance level was set at $P<0.05$. For the statistical analysis of the differences in protein expression pattern, Student's t-test was used, which was integrated in the PDQuest Analysis software version 8.0.1 Advanced (Bio-Rad, Hercules, CA, USA) and $P<0.05$ was considered as significant.

\section{Results}

\section{Differentially expressed ileal proteins}

Comparative proteomic analysis of the $\mathrm{T} 1$ group versus the $\mathrm{C}$ group revealed 10 spots with a significantly decreased expression. Spots No. 5 and No. 7 , identified as proteasome subunit beta type- 3 and inorganic pyrophosphatase, showed the highest decrease in the T1 group (0.35 and 0.39-fold decrease, respectively, Figure 1A). The T2 diet caused a significant overexpression of 24 ileal protein spots when compared to the $\mathrm{C}$ diet. Among these proteins, the most pronounced changes were observed in the expressions of myosin regulatory light polypeptide 9 (spot No. 24) and protein-glutamine gamma-glutamyltransferase 2 (spot No. 3) (4.47 and 3.36-fold increase, respectively, Figure 1B). The analysis of intragroup variation showed that $\mathrm{CV}$ amounted to $51.40 \%, 50.95 \%$ and $50.10 \%$ for group C, T1 and $\mathrm{T} 2$, respectively.

Among 34 protein spots with altered expression, 33 were successfully identified and the majority of these proteins $(85 \%)$ were recognized based on Sus scrofa identities. Protein identification was approved when matches had a MASCOT score greater than 70 . Proteins were identified with peptide matches ranging from 6 to 34 .
The experimental $\mathrm{M}_{\mathrm{r}}$ and $\mathrm{pI}$ value of the identified proteins ranged from 19.90 to $105.80 \mathrm{kDa}$ and from 3.80 to 7.70 , respectively. It should be noted that the high-molecular weight proteins $(>30 \mathrm{kDa})$ were in the majority among the identified proteins $(70 \%)$. Small shifts between experimental and theoretical $\mathrm{M}_{\mathrm{r}}$ and $\mathrm{pI}$ values were observed in all analysed spots. Lists of proteins containing detailed information concerning 2-DE and MALDI-TOF coordinates of each individual protein spots are provided in Tables 2 and 3. All identified ileal proteins were categorized according to their subcellular localization as well as biological functions on the basis of the UniProtKB database (Tables 1 and 2).

\section{Blood plasma biochemical parameters}

There were no effects of inulin level on phosphorus, magnesium, calcium and iron concentrations, whereas chloride concentration was higher in piglets fed T2 than T1 diet. Feeding the T2 diet decreased PAB values $(P<0.05)$ in comparison to the $\mathrm{C}$ and T1 groups (Table 3 ).

Table 3. Biochemical blood parameters in pigs fed control diet and diets supplemented with $1 \%$ (T1) and $3 \%$ (T2) of native chicory inulin

\begin{tabular}{|c|c|c|c|c|c|}
\hline \multirow{2}{*}{$\begin{array}{l}\text { Biochemical } \\
\text { parameters }\end{array}$} & \multicolumn{3}{|l|}{ Group } & \multirow{2}{*}{ SEM } & \multirow{2}{*}{$P$-value } \\
\hline & $\bar{C}$ & T1 & $\mathrm{T} 2$ & & \\
\hline Chloride, $\mathrm{mmol} / \mathrm{l}$ & $97.06^{\mathrm{ab}}$ & $93.75^{\mathrm{a}}$ & $101.56^{b}$ & 1.118 & 0.009 \\
\hline Phosphorus, mmol/l & 2.60 & 2.79 & 2.54 & 0.065 & 0.266 \\
\hline Magnesium, mmol/l & 0.47 & 0.48 & 0.51 & 0.018 & 0.733 \\
\hline Calcium, mmol/l & 2.97 & 3.01 & 2.82 & 0.062 & 0.463 \\
\hline Iron, $\mu \mathrm{mol} / /$ & 18.27 & 23.89 & 19.64 & 1.778 & 0.4122 \\
\hline PAB values, $\mathrm{HK}$ & $303^{b}$ & $297^{b}$ & $201^{\mathrm{a}}$ & 15.30 & 0.002 \\
\hline
\end{tabular}

PAB - prooxidant-antioxidant balance; ${ }^{\text {ab }}$ - mean values with different superscripts within the same row are significantly different at $P<0.05$ 


\section{Discussion}

Proper gut functioning depends mainly on four components (mechanical, chemical, immunological and biological) forming the intestinal mucosal barrier that provides the anterior defensive line separating the internal tissue and the surrounding environment. The biological barrier is a mutually dependent microecosystem composed of intestinal microbiota, which mainly consists of commensal bacteria living on mucosal surfaces (Ribet and Cossart, 2015; Wang et al., 2016). The distal ileum of pigs contains significantly higher amount of bacteria $\left(10^{9}\right.$ $\mathrm{CFU} / \mathrm{g}$ ), with a clear dominance of Gram-positive lactic acid bacteria, especially Lactobacillus spp. in comparison to humans and other monogastric animals (Konstantinov et al., 2006). As a consequence, more rapid inulin fermentation may occur, which is accompanied by an elevated production and absorption of short-chain fatty acids (SCFAs) (Böhmer et al., 2005; Loh et al., 2006).

The results of our previous study on growing pigs (Barszcz et al., 2018) demonstrated that both levels of native inulin increased fructan concentrations in the caecum, proximal, middle and distal colon, indicating that inulin had reached the large intestine. However, these results also showed that both dietary inulin levels did not affect relative amounts of E. coli, Lactobacillus, Bifidobacterium and Clostridium spp. in the digesta samples from different colon segments. These findings are consistent with the results of other studies performed in pigs (Loh et al., 2006; Paßlack et al., 2012).

Based on the results of our previous research (Herosimczyk et al., 2017; Lepczyński et al., 2017) and the results of the present study, it is clear that the dietary level of inulin has a direct impact on the total amount of expressed proteins as well as the direction of their changes. The expression of some ileal proteins, such as the ribonuclease inhibitor, elongation factor and proteasome subunit beta showed an opposite direction of changes in response to the experimental diets. The above-mentioned proteins were found to be down-regulated when pigs were fed the diet supplemented with $1 \%$ of inulin, whereas the diet with $3 \%$ inulin addition caused their up-regulation. Therefore, changes in protein expression caused by the $\mathrm{T} 1$ and $\mathrm{T} 2$ diets will be addressed separately in the discussion.

Ileal protein changes in response to the $\mathrm{T} 1$ diet. Lower expression levels were observed for 10 proteins in pigs fed the $\mathrm{T} 1$ diet in comparison to the $\mathrm{C}$ group. Two of these proteins, i.e. aldose reductase (AR) and peroxiredoxin-2 (PRDX2) were closely associated with oxidative stress. AR has been shown to efficiently metabolize reactive aldehydes yielding products that activate and perpetuate inflammatory process (Ramana et al., 2006; Srivastava et al., 2011). Studies performed on cellular and animal models revealed that AR was able to mediate the activation of NF- $\kappa \mathrm{B}$, an oxidative stress inducing factor, as well as transcription induction of cytokines and chemokines (Ramana et al., 2006; Reddy et al., 2009; Srivastava et al., 2011). AR inhibitors are known as anti-inflammatory agents, therefore, it seems that the down-regulation of ileal AR, observed in the present study, may reflect enhanced defence against oxidative stress to counteract endogenous reactive oxygen species (ROS) accumulation. Moreover, PRDX2 expression level was also decreased in response to $1 \%$ inulin addition. This protein is predominantly known as a cellular antioxidant exerting a critical role in oxidative stress prevention caused by a sudden increase in ROS generation. However, further characterization has revealed that PRDX2 may also induce inflammatory cytokine production, and thus be involved in the redox-dependent signalling mechanism during inflammation (Mullen et al., 2015). This finding may support a general hypothesis concerning putative anti-inflammatory and antioxidant effects of inulin on the intestinal mucosa layer (Pasqualetti et al., 2014).

Previously, it was found that both experimental diets reduced the expression of structural proteins and those related to cell mobility and proliferation in the liver of piglets (Herosimczyk et al., 2017). Similarly, this study demonstrated decreased expression of two structural proteins (lamin-B1, plastin-2), proteins directly or indirectly involved in DNA, RNA, protein and polysaccharide synthesis (inorganic pyrophosphatase, elongation factor 1-gamma), as well as those associated with the regulation of cell proliferation and apoptosis (histone-binding protein RBBP4, phosphatidylethanolamine-binding protein 1) in response to the T1 diet. Down-regulation of these proteins suggests that the $\mathrm{T} 1$ diet might have limited the turnover rate of ileal epithelial cells, which is in line with the findings of previous experiments conducted on growing piglets fed a formula supplemented with $0.3 \%$ of inulin (Kien et al., 2006, 2007).

Ileal protein changes in response to the $\mathrm{T} 2$ diet. Previously, in weaned pigs fed diet supplemented with $10 \%$ of dietary fructooligosaccharides (FOS) for 10 days an increase in the number of cecal epithelial, mitotic and mucin-containing cells was demonstrated (Tsukahara et al., 2003). 
These authors postulated that the observed effect was mainly due to the increased luminal concentration of not only butyrate, but also valerate. This is consistent with a previous study of Barszcz et al. (2018). Although the concentrations of butyric and valeric acids did not reach statistical significance, they were elevated in different segments of the large intestine in pigs fed diet with $3 \%$ of native inulin in comparison to the control group (Barszcz et al., 2018). The results of the current study seem to support the above-mentioned findings, as the upregulation of several proteins involved in intracellular molecular mechanisms controlling cell division and growth was revealed.

An increase in the expression of ileal cytoskeletal proteins, proteins engaged in the regulation of mRNA transcription, RNA binding and translation activity (40 S ribosomal protein SA, ribonuclease inhibitor, elongation factor 1-delta isoform X1), proteins involved in protein folding (transitional endoplasmic reticulum ATPase, protein disulfide isomerase) as well as those catalysing protein posttranslational modifications, mainly glycosylation (phosphomannomutase 2, protein-glutamine gamma-glutamyltransferase 2) was shown in pigs fed the T2 diet. It should be also noted that transitional endoplasmic reticulum ATPase is implicated in the regulation of the G2-M transition stage, thus the increased expression of this protein found in the T2 group seemed to drive cell cycle progression from one stage to another (Ye et al., 2017). Similar results were reported in other studies that showed higher protein synthesis rates in the distal part of the small intestine as well as in the caecum and colon of rats fed diet containing $8 \%$ of pectin for 14 days (Pirman et al., 2007). The observed trophic effect was associated with enhanced total SCFA production, mainly butyrate which is known for its role as a major mediator stimulating intestinal mucosal cell proliferation. Apart from its function as an energy substrate for colonocytes, butyrate has also been shown to directly stimulate the release of glucagon-like peptide-2 (GLP-2) from the enteroendocrine $\mathrm{L}$ cells, located in the terminal ileum and colon (Burrin et al., 2001). GLP-2 acts via binding to a $\mathrm{G}$ protein-coupled membrane receptor (GLP-2R) localized along the gastrointestinal tract, including ileum (Tappenden et al., 2003). This protein exerts a trophic effects on the intestinal mucosa, both in small and large intestines, where it stimulates cell proliferation and inhibits apoptosis. In this regard, secretion of GLP-2 via increased butyrate concentration in the ileum might be the one of a possible explanation for the enhanced expression of proteins involved in controlling cell division and growth, observed in the group of pigs fed the $\mathrm{T} 2$ diet. It might be anticipated that the main cause for diametrically opposite effect of the $\mathrm{T} 1$ on the proteome changes might be attributed to decreased values of the butyric acid observed in the large intestine of pigs fed diet with $1 \%$ of inulin in comparison to the control group (Barszcz et al., 2018).

Furthermore, an up-regulation of two gene products, i.e. annexin A5 (AnxA5) and sorcin (CP22), which belong to the family of calcium-binding proteins was demonstrated in this study. AnxA5 and CP22 are primarily involved in the regulation of calcium homeostasis by binding $\mathrm{Ca}^{2+}$ as well as the regulation of calcium channel activity, increasing, in consequence, the concentration of this ion in the endoplasmic reticulum and mitochondria (Ilari et al., 2015). Elevated expression of calcium-binding proteins is considered as a possible mechanism of increasing intestinal calcium absorption and, as a result, its plasma levels. However, we did not find any effect of inulin level on plasma calcium concentration, which is consistent with our previous study (Lepczyński et al., 2016).

\section{Conclusions}

Several new ileal proteins affected by dietary level of native chicory inulin in growing pigs were revealed in the study. Based on the biological role of those protein, it is most likely that supplementation with $1 \%$ inulin caused down-regulation, whereas $3 \%$ inulin addition induced substantial up-regulation of proteins engaged in transcriptional and translational activity, folding and posttranslational modification, which may indicate a stimulating effect of this diet on the intestinal cell proliferation. The results of this study might be considered as preliminary since further confirmation using more sophisticated quantitative proteomic tools is required to better understand and answer the unresolved issues concerning the mechanism underlying inulin effect on the ileum in growing pigs. Nevertheless, a general insight into how inulin molecules or their fermentation endproducts may induce changes in protein expression patterns in the ileum was presented.

\section{Acknowledgements}

This study was supported by a grant from the National Centre of Science, Poland (Project No. 2012/05/D/NZ9/01604). 


\section{References}

Barszcz M., Taciak M., Skomiał J., 2018. Influence of different inclusion levels and chain length of inulin on microbial ecology and the state of mucosal protective barrier in the large intestine of young pigs. Anim. Prod. Sci. 58, 1109-1118, https://doi. org/10.1071/AN16014

Böhmer B.M., Branner G.R., Roth-Maier D.A., 2005. Precaecal and faecal digestibility of inulin (DP 10-12) or an inulin/Enterococcus faecium mix and effects on nutrient digestibility and microbial gut flora. J. Anim. Physiol. Anim. Nutr. 89, 388-396, https://doi.org/10.1111/j.1439-0396.2005.00530.x

Burrin D.G., Petersen Y., Stoll B., Sangild P., 2001. Glucagon-like peptide 2: a nutrient-responsive gut growth factor. J. Nutr. 131, 709-712, https://doi.org/10.1093/jn/131.3.709

Herosimczyk A., Lepczyński A., Ożgo M., Barszcz M., JaszczukKubiak E., Pierzchała M., Tuśnio A., Skomiał J., 2017. Hepatic proteome changes induced by dietary supplementation with two levels of native chicory inulin in young pigs. Livest. Sci. 203, 54-62, https://doi.org/10.1016/j.livsci.2017.07.004

Ilari A., Fiorillo A., Poser E., Lalioti V.S., Sundell G.N., Ivarsson Y., Genovese I., Colotti G., 2015. Structural basis of Sorcinmediated calcium-dependent signal transduction. Sci. Rep. 5, 16828, https://doi.org/10.1038/srep16828

Kien C.L., Blauwiekel R., Bunn J.Y., Jetton T.L., Frankel W.L., Holst J.J., 2007. Cecal infusion of butyrate increases intestinal cell proliferation in piglets J. Nutr. 137, 916-922, https:// doi.org/10.1093/jn/137.4.916

Kien C.L., Schmitz-Brown M., Solley T., Sun D., Frankel W.L., 2006. Increased colonic luminal synthesis of butyric acid is associated with lowered colonic cell proliferation in piglets. J. Nutr. 136, 64-69, https://doi.org/10.1093/jn/136.1.64

Koliakos G., Hamidi Alamdari D., 2009. Measurement of the oxidantsantioxidants balance in liquids. United States Patent Application Publication No. US 2009/0123956 A1 (USA)

Konstantinov S.R., Poznanski E., Fuentes S., Akkermans A.D.L., Smidt H., de Vos W.M., 2006. Lactobacillus sobrius sp. nov., abundant in the intestine of weaning piglets. Int. J. Syst. Evol. Microbiol. 56, 29-32, https://doi.org/10.1099/ijs.0.63508-0

Lepczyński A., Herosimczyk A., Barszcz M., Ożgo M., Taciak M., Skomiał J., 2016. Inulin-type fructans trigger changes in iron concentration and activity of bone metabolism biomarkers in blood plasma of growing pigs. J. Anim. Feed Sci. 25, 343-347, https://doi.org/10.22358/jafs/67471/2016

Lepczyński A., Herosimczyk A., Ożgo M., Marynowska M., Pawlikowska M., Barszcz M., Taciak M., Skomiał J., 2017. Dietary chicory root and chicory inulin trigger changes in energetic metabolism, stress prevention and cytoskeletal proteins in the liver of growing pigs - a proteomic study. J. Anim. Physiol. Anim. Nutr. 101, e225-e236, https://doi.org/10.1111/jpn.12595

Loh G., Eberhard M., Brunner R.M., Hennig U., Kuhla S., Kleessen B., Metges C.C., 2006. Inulin alters the intestinal microbiota and short-chain fatty acid concentrations in growing pigs regardless of their basal diet. J. Nutr. 136, 1198-1202, https://doi. org/10.1093/jn/136.5.1198

Mensink M.A., Frijlink H.W., van der Voort Maarschalk K., HinrichsW.L.J., 2015. Inulin, a flexible oligosaccharide I: Review of its physicochemical characteristics. Carbohydr. Polym. 130, 405-419, https://doi.org/10.1016/j.carbpol.2015.05.026

Mullen L., Hanschmann E.-M., Lillig C.H., Herzenberg L.A., Ghezzi P., 2015. Cysteine oxidation targets peroxiredoxins 1 and 2 for exosomal release through a novel mechanism of redoxdependent secretion. Mol. Med. 21, 98-108, https://doi. org/10.2119/molmed.2015.00033
Niness K.R., 1999. Inulin and oligofructose: what are they? J. Nutr. 129, 1402S-1406S, https://doi.org/10.1093/jn/129.7.1402S

Pasqualetti V., Altomare A., Guarino M.P.L., Locato V., Cocca S., Cimini S., Palma R., Alloni R., De Gara L., Cicala M., 2014. Antioxidant activity of inulin and its role in the prevention of human colonic muscle cell impairment induced by lipopolysaccharide mucosal exposure. PLoS ONE 9, e98031, https:// doi.org/10.1371/journal.pone.0098031

Paßlack N., Al-samman M., Vahjen W., Männer K., Zentek J., 2012. Chain length of inulin affects its degradation and the microbiota in the gastrointestinal tract of weaned piglets after a shortterm dietary application. Livest. Sci. 149, 128-136, https://doi. org/10.1016/j.livsci.2012.07.005

Patterson J.K., Yasuda K., Welch R.M., Miller D.D., Lei X.G., 2010. Supplemental dietary inulin of variable chain lengths alters intestinal bacterial populations in young pigs. J. Nutr. 140, 2158-2161, https://doi.org/10.3945/jn.110.130302

Pirman T., Ribeyre M.C., Mosoni L., Rémond D., Vrecl M., Salobir J., Patureau Mirand P., 2007. Dietary pectin stimulates protein metabolism in the digestive tract. Nutrition 23, 69-75, https:// doi.org/10.1016/j.nut.2006.09.001

Ramana K.V., Bhatnagar A., Srivastava S., Yadav U.C., Awasthi S., Awasthi Y.C., Srivastava S.K., 2006. Mitogenic responses of vascular smooth muscle cells to lipid peroxidation-derived aldehyde 4-hydroxy-trans-2-nonenal (HNE): role of aldose reductase-catalyzed reduction of the HNE-glutathione conjugates in regulating cell growth. J. Biol. Chem. 281, 1765217660, https://doi.org/10.1074/jbc.M600270200

Reddy A.B.M., Srivastava S.K., Ramana K.V., 2009. Anti-inflammatory effect of aldose reductase inhibition in murine polymicrobial sepsis. Cytokine 48, 170-176, https://doi.org/10.1016/j. cyto.2009.07.004

Ribet D., Cossart P., 2015. How bacterial pathogens colonize their hosts and invade deeper tissues. Microbes Infect. 17, 173-183, https://doi.org/10.1016/j.micinf.2015.01.004

Srivastava S.K., Yadav U.C.S., Reddy A.B.M. et al., 2011. Aldose reductase inhibition suppresses oxidative stress-induced inflammatory disorders. Chem. Biol. Interact. 191, 330-338, https://doi.org/10.1016/j.cbi.2011.02.023

Tappenden K.A., Albin D.M., Bartholome A.L., Mangian H.F., 2003. Glucagon-like peptide-2 and short-chain fatty acids: a new twist to an old story. J. Nutr. 133, 3717-3720, https://doi. org/10.1093/jn/133.11.3717

Tsukahara T., Iwasaki Y., Nakayama K., Ushida K., 2003. Stimulation of butyrate production in the large intestine of weaning piglets by dietary fructooligosaccharides and its influence on the histological variables of the large intestinal mucosa. J. Nutr. Sci. Vitaminol. (Tokyo) 49, 414-421, https://doi.org/10.3177/ jnsv. 49.414

Wang K., Wu L.-y., Dou C.-z., Guan X., Wu H.-g., Liu H.-r., 2016. Research advance in intestinal mucosal barrier and pathogenesis of Crohn's disease. Gastroenterol. Res. Pract. 2016, 9686238, https://doi.org/10.1155/2016/9686238

Yasuda K., Maiorano R., Welch R.M., Miller D.D., Lei X.G., 2007. Cecum is the major degradation site of ingested inulin in young pigs. J. Nutr. 137, 2399-2404, https://doi.org/10.1093/ jn/137.11.2399

Ye Y., Tang W.K., Zhang T., Xia D., 2017. A mighty "Protein Extractor" of the cell: structure and function of the p97/CDC48 ATPase. Front. Mol. Biosci. 4, 39, https://doi.org/10.3389/ fmolb.2017.00039 